Vol. 3 | No. 1 | 2022 | Hal. 1-8

\title{
MANAJEMEN SAMPAH DAN DIGITALISASI DATABASE TPST 3R MELALUI PEMBERDAYAAN MASYARAKAT
}

\author{
Ita Athia*, Ashifa Maharani, Desti Ikromah, Vicky Dwi, Dwi Bella, Siti Nur Aini, M. \\ Ivan, Andy Prasetya, M. Rizal, Yusril Amar \\ Fakultas Ekonomi dan Bisnis, Universitas Islam Malang \\ *korespondensi email: itaathia@unisma.ac.id
}

\begin{abstract}
ABSTRAK
Sampah menjadi problem tersendiri bagi lingkungan masyarakat, baik di pedesaan maupun di perkotaan. Kegiatan pengabdian ini dilakukan untuk meningkatkan partisipasi masyarakat Desa Kendalpayak, Kabupaten Malang, dalam program pengelolaan sampah untuk menciptakan lingkungan yang bersih, memperbaiki karakteristik sampah, menambah nilai ekonomis sampah dan mengadministrasikan data sampah secara digital. Metode kegiatan yang dilakukan adalah (1). Observasi lapangan dan wawancara pada pengelola TPST Langgeng Jaya. (2). Sosialisasi dan mengedukasi masyarakat desa Kendalpayak. (3). Melakukan program 3R (Reduce-Reuse-Recylcle). (4). Mentranformasi database TPST 3R Langgeng Jaya ke arah digital. (5). Monitoring dan evaluasi hasil. Hasil yang didapatkan setelah kegiatan berlangsung antara lain adalah masyarakat lebih sadar akan sampah dan ikut berpartisipasi dalam kegiatan memilih, memilah, mengolah dan memanfaatkan sampah yang telah didaur ulang.
\end{abstract}

Kata Kunci: manajemen sampah; digitalisasi; TPST 3R; pemberdayaan masyarakat

\section{PENDAHULUAN}

Salah satu permasalahan lingkungan yang dihadapi oleh masyarakat modern adalah masalah lingkungan akibat sampah yang tidak dikelola dengan baik. Kajian pengembangan Tempat Pengelolaan Sampah Terpadu (TPST) telah digaungkan baik oleh pemerintah pusat maupun pemerintah daerah (Marliani, 2014). Dalam penyelenggaraannya, kegiatan pengelolaan sampah bukan hanya menjadi tanggung jawab pemerintah saja, melainkan tanggung jawab semua elemen masyarakat. Keberhasilan dan pengelolaan sampah untuk menghasilkan lingkungan yang nyaman dan bersih membutuhkan partisipasi aktif dari pemerintah pusat, pemerintah daerah, masyarakat, kelompok swadaya masyarakat dan pengurus atau pengelola TPST (Elamin et al., 2018; Rahim, 2020).

TPST 3R langgeng Jaya bertempat di dusun Cerme, Desa Kendalpayak, Kabupaten Malang. TPST 3R Langgeng Jaya merupakan tempat pembuangan sampah terpadu dimana semua sampah dari desa Kendalpayak dikumpulkan, kemudian dipilih dan dipilah. Semua sisa yang dihasilkan oleh masyarakat Kendalpayak sehari-harinya dikirimkan ke tempat ini. Sampah yang dihasilkan masyarakat dapat diklasifikasikan menjadi beberapa jenis, antara lain yaitu sampah organik, sampah non organik dan sampah residu. Masing-masing jenis sampah memiliki karakterisik, cara pengolahan dan keperuntukan yang berbeda-beda. Selama ini pembuangan yang dilakukan masyarakat masih bercampur, sehingga menyulitkan pengelola TPST Langgeng Jaya dalam hal pemilihan dan pemilahan sampah. Hal 
ini menjadi indikasi bahwa kesadaran dari masyarakat mengenai penanganan sampah dan implikasinya terhadap lingkungan hidup sekitar masih kurang.

Prinsip 3R, yaitu Reuse, Reduce dan Recycle telah diadaptasi menjadi sistem yang banyak dipakai sebagai cara penangan sampah. Penanganan sampah dengan penyelenggaraan TPS 3R menekankan pada cara pengurangan, pemanfaatan dan pengolahan (Kementrian PUPR, 2017). Implementasi 3R adalah sistem yang mengusung cara sebagai berikut: 1). Dengan mengurangi barang-barang yang berpotensi untuk menambah penimbunan sampah; 2). Mendaur ulang sampah atau mengolahnya menjadi barang yang baru sehingga mempunyai nilai ekonomis dan layak jual; 3). Memanfaatkan kembali sampah atau barang yang telah dibuang untuk hal yang bermanfaat.

Kegiatan pengabdian ini mempunyai beberapa tujuan, antara lain: 1). Untuk meningkatkan kesadaran dan partisipasi aktif dari masyarakat Dusun Cerme untuk melakukan pengurangan sampah serta melakukan pemilihan dan pemilahan sampah organik dan sampah non organik mulai dari rumah masing-masing; 2). Menciptakan lingkungan yang bersih dan nyaman untuk ditinggali; 3). Memperbaiki karakteristik sampah supaya lebih mudah untuk diolah atau digunakan kembali; 4). Menambah pengetahuan, ketrampilan dan taraf perekonomian masyarakat melalui pemanfaatan sampah; dan yang terakhir 5). Memperbaiki pengadministrasian database TPST 3R Langgeng Jaya yang selama ini masih dikelola secara manual untuk ditransformasikan ke arah digital.

\section{METODE}

Kegiatan pengabdian kepada masyarakat ini diselenggarakan sebagai implementasi program kerja Kandidat Sarjana Mengabdi (KSM-tematik) yang dilaksanakan oleh kelompok 34 selama bulan Agustus 2021. Sasaran kegiatan dilakukan pada masyarakat Dusun Cerme, Desa Kendalpayak, Kabupaten Malang dan pada lokasi TPST 3R Langgeng Jaya. Pelaksanaan kegiatan ini menggunakan pendekatan pemberdayaan masyarakat, yaitu dengan melibatkan peran aktif dari masyarakat dan pihak yang terkait dengan pengelolaan sampah. Partisipasi masyarakat dalam pengelolaan lingkungan merupakan salah satu faktor yang harus diperhitungkan seiring dengan kondisi lingkungan yang semakin memprihatinkan (Hernawati et al., 2005; Yunik'ati et al., 2019). Sedangkan partisipasi menurut Sastropoetro (1988) adalah keterlibatan yang bersifat spontan dan disertai kesadaran serta tanggung jawab terhadap kelompok untuk mencapai tujuan bersama.

Adapun tahapan kegiatan pelaksanaan pengabdian diawali dengan tahap persiapan untuk melihat kondisi lingkungan dan merumuskan permasalahan serta alternatif solusi yang ditawarkan. Selanjutnya dilakukan pengorganisasian untuk menentukan pihak-pihak yang terlibat, peran serta tanggung jawabnya. Dilanjutkan dengan kegiatan pelaksanaan program, yang terdiri dari sosialisasi dan edukasi, pendampingan dan pelatihan serta praktek, yang terakhir dilakukan monitoring dan evaluasi keberhasilan pelaksanaan program. Secara rinci, metode pengabdian masyarakat ini disajikan dalam tabel 1 yang menjelaskan tentang metode pelaksanaan program.

Tabel 1. Metode Pelaksanaan Program

\begin{tabular}{|c|c|c|c|}
\hline Tahapan & Metode & Kegiatan & Sasaran \\
\hline $\begin{array}{l}\text { Tahap } \\
\text { pertama }\end{array}$ & Persiapan & $\begin{array}{l}\text { 1. Observasi lapangan } \\
\text { 2. Wawancara } \\
\text { responden dan pihak } \\
\text { terkait }\end{array}$ & $\begin{array}{l}\text { 1. Melihat kondisi lingkungan masyarakat dusun Cerme } \\
\text { 2. Melakukan wawancara awal pada pemerintah desa } \\
\text { dan pengelola TPST Langgeng Jaya } \\
\text { 3. Mengidentifikasi permasalahan dan solusi yang } \\
\text { ditawarkan }\end{array}$ \\
\hline Tahap Kedua & $\begin{array}{l}\text { Pengorganisa } \\
\text { sian }\end{array}$ & $\begin{array}{l}\text { 1. Menentukan program } \\
\text { kegiatan pengabdian }\end{array}$ & $\begin{array}{l}\text { 1. Kegiatan yang dipilih adalah: sosialisasi dan edukasi } \\
\text { pada masyarakat, praktek reduce, reuse \& recycle }\end{array}$ \\
\hline
\end{tabular}




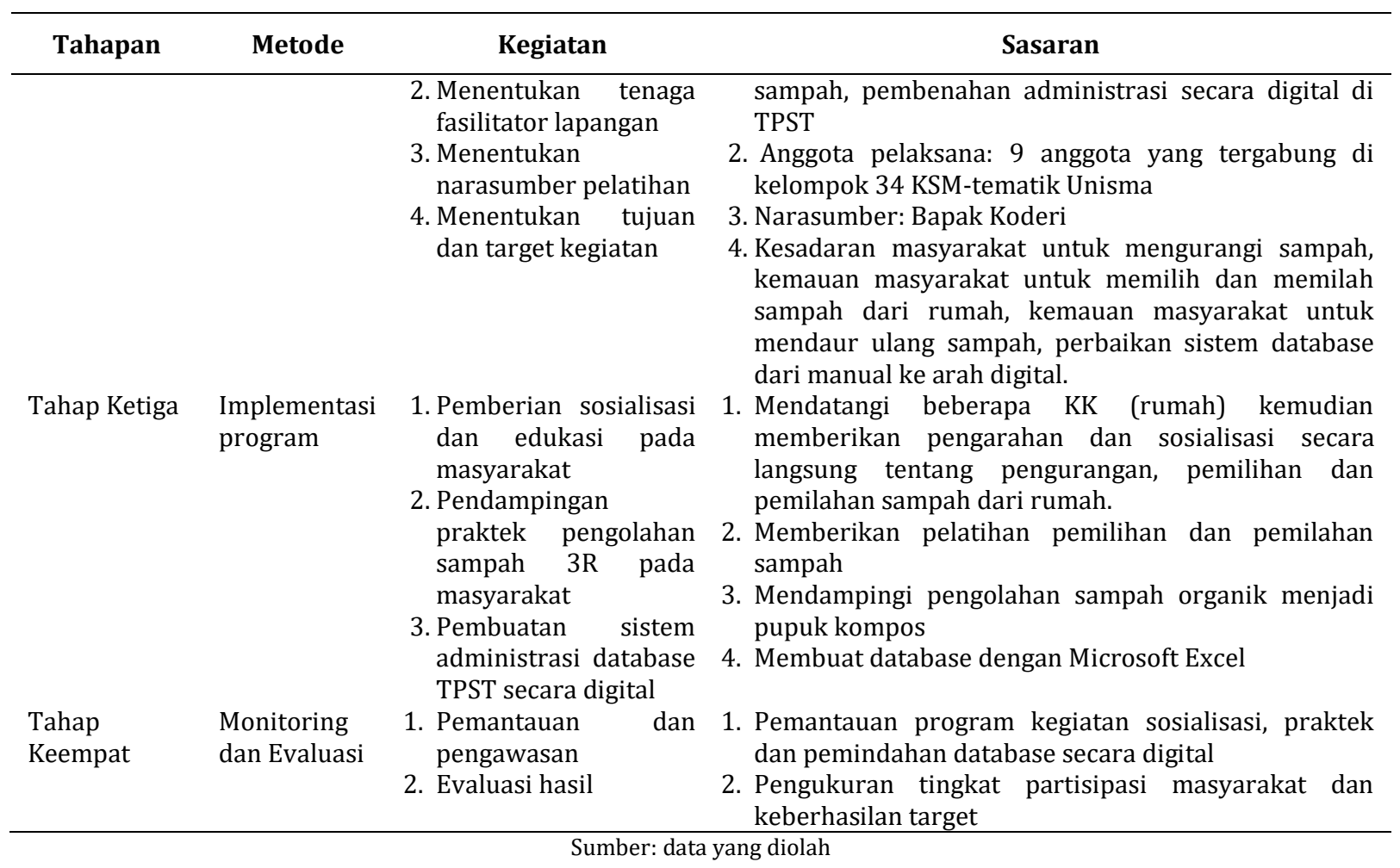

\section{HASIL DAN PEMBAHASAN}

Kendalpayak merupakan sebuah desa yang terletak di Kabupaten Malang, Jawa Timur, yang wilayahnya dibagi menjadi lima dusun, yaitu Dusun Watudakon, Cerme, Kendalpayak dan Segaran. Mayoritas penduduknya berprofesi sebagai petani padi, tebu dan jagung. Sisanya berprofesi sebagai peternak sapi, karyawan, buruh pabrik, dan PNS. Teknologi informasi yang diterapkan pada masyarakat desa Kendalpayak sudah mulai berkembang. Hal ini dibuktikan dengan masyarakat desanya yang sudah mulai bersentuhan dan familier dengan internet dan pemanfaatan media sosial serta aplikasi mobile lainnya. Desa Kendalpayak juga dikenal sebagai wilayah yang berkembang, karena lokasinya sebagai jalur lintas utama dari Kota Malang menuju Kota Blitar, Dampit, Lumajang dan Malang bagian selatan. Kehidupan sosial masyarakatnya sudah bercampur, antara penduduk asil dan penduduk pendatang.

Seiring dengan meniningkatnya populasi penduduknya, permasalahan lingkungan yang timbul adalah permasalahan residu atau sampah yang dihasilkan oleh masyarakatnya. Permasalahan pengelolaan persampahan merupakan salah satu isu utama yang sedang dihadapi oleh Kabupaten/Kota di beberapa wilayah Indonesia. Permasalahan muncul tidak hanya karena volume yang bertambah, namun jenis dan karakter sampah yang timbul juga semakin bertambah. Kecenderungan masyarakat menganut gaya hidup yang serba instan banyak menghasilkan sampah yang tidak kondusif bagi lingkungan (Hartono et al., 2020).

Sarana dan prasarana yang telah disediakan pemerintah desa Kendalpayak sudah cukup memadai. Hanya saja kesadaran dari masyarakat melalui pemilihan dan pemilahan sampah dari rumah belum banyak diimplementasikan. Sistem pengelolaan sampah yang baik dan efisien bertujuan untuk mengurangi dampak negatif terhadap lingkungan, mewujudkan lingkungan yang baik, meningkatkan tingkat kesehatan masyarakat dan menumbuhkan kreatifitas masyarakat dalam upaya re-use dan re-cycle sampah (Roos, 2021).

Dari kegiatan observasi dan wawancara yang dilakukan pada tahap persiapan, info yang didapat adalah bahwa, pengelolaan sampah di Desa Kendalpayak ini sebagian besar masih memakai cara: kumpul-angkut-buang. Selanjutnya adalah kurangnya partisipasi 
masyarakat sebagai pelaku dalam mengelola sampah di pemukiman. Serta aspek kelembagaan mengenai aspek efektivitas dan efisiensi dalam pengelolaannya, baik dilihat secara pengadministrasian data serta pengelolaan biayanya. Oleh karena itu solusi yang ditawarkan dari kegiatan pengabdian masyarakat ini adalah pengelolaan sampah yang berbasis pada pemberdayaan masyarakat serta perbaikan sistem kelembagaan sampah melalui transformasi digital.

\section{Melakukan sosialisasi dan edukasi pada masyarakat tentang pengelolaan sampah dari rumah}

Kampanye PERILAKU HIDUP BERSIH perlu didengungkan pada pola kehidupan masyarakat. Salah satu program kampanye adalah manajemen sampah yaitu mengajak masyarakat untuk berpartisipasi dan meningkatkan perannya dalam kegiatan 3R (Reduce, Reuse dan Recycle), pengurangan sampah, pemanfaatan sampah dan pengolahan sampah. Upaya yang dilakukan adalah dengan mendatangi beberapa KK di dusun Cerme dan dusun Segaran, desa Kendalpayak untuk memberikan pengarahan tentang kebiasaan masyarakat untuk membuang sampah pada tempat yang telah disediakan pemerintah desa (bukan membuang di sungai atau di tanah lapang). Mengedukasi tentang pentingnya mengelola sampah dari rumah. Memberikan informasi tentang pentingnya mengurangi/membatasi sampah yang terbuat dari plastik, foam dan bahan sejenis yang mempunyai potensi sulit terurai dalam tanah. Kemudian memberikan pengarahan tentang pentingnya melakukan pemilahan sampah sesuai dengan jenisnya, yaitu sampah organik, sampah anorganik dan sampah yang memerlukan penanganan khusus.

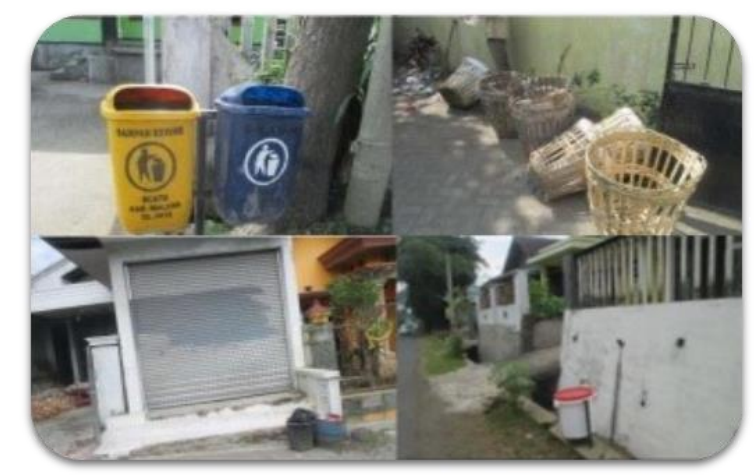

Gambar 1. Membiasakan masyarakat membuang sampah pada tempatnya

\section{Memberikan pelatihan pemilihan dan pemilahan sampah}

Berdasarkan survei yang dilakukan oleh Cipta Karya.PU (2013), masih banyak TPS 3R dan TPST di Kabupaten Malang yang belum ada aktifitas pemilahan. Pengelolaan TPS 3R dan TPST sangat tergantung spenuhnya pada masyarakat, sehingga dibutuhkan swadaya yang kuat supaya kegiatan TPS 3R dan TPST dapat maksimal. Masyarakat harus dibiasakan melakukan kegiatan pemilihan dan pemilahan sampah dari rumah masingmasing. Sampah bisa dibedakan menjadi tiga macam, yaitu: 1). Sampah organik atau sampah basah, yaitu sampah yang berasal dari makhluk hidup, seperti sampah dapur, daun-daunan, sisa makanan. Sampah jenis ini bisa terdegradasi (membusuk atau hancur) secara alami. 2). Sampah anorganik atau sampah kering, yaitu sampah yang tidak dapat terdegradasi secara alami, contohnya: plastik, kaleng, foam, botol kaca, besi, karet, dll. 3). Sampah spesifik, yaitu sampah yang membutuhkan penanganan tertentu karena berpotensi membahayakan manusia dan makhluk hidp lainnya, contoh: baterai, jarum suntik, obat-obatan, cairan kimia, dll. 


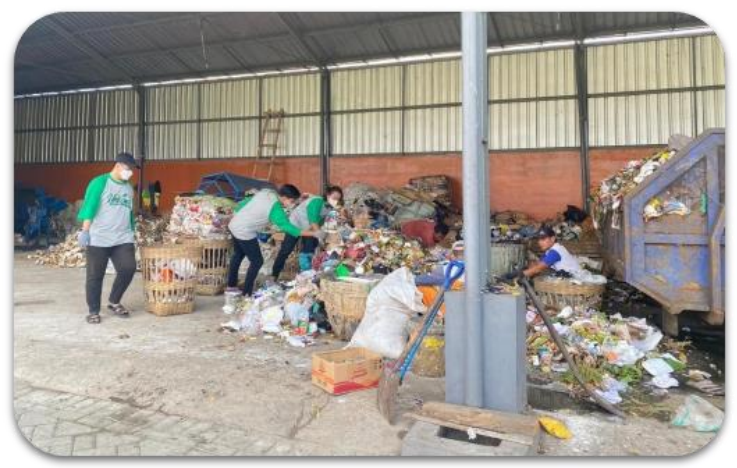

Gambar 2. Kondisi TPST 3R Langgeng Jaya yang belum ada pemilahan sampah

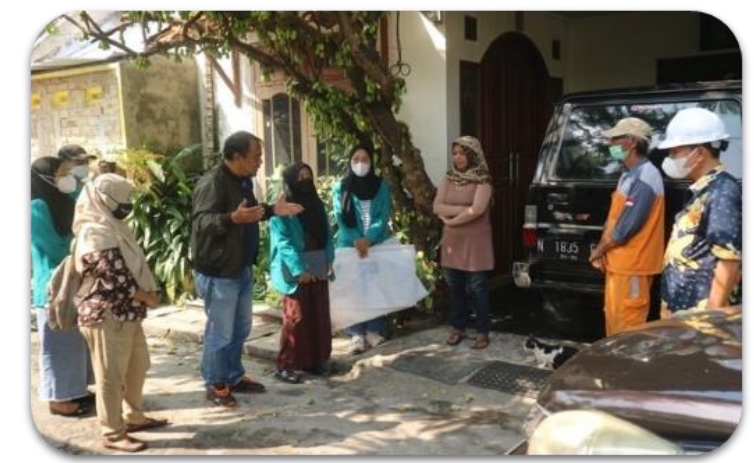

Gambar 3. Sosialisasi pada masyarakat tentang pemilihan dan pemilahan sampah dari rumah

\section{Mendampingi pengolahan sampah organik menjadi pupuk kompos}

Upaya pengolahan sampah organik menjadi kompos sangat lazim dilakukan. Pembuatan pupuk kompos dilakukan dengan memanfaatkan sampah basah yang dihasilkan oleh setiap rumah tangga dalam masyarakat. Dalam tahap ini, tim pengabdi mengajak ibu-ibu rumah tangga untuk memanfaatkan sisa olahan dapur, sisa makanan, sampah daundaunan yang telah dipilih dan dipilah sebelumnya untuk diolah kembali menjadi pupuk kompos. Setelah terkumpul beberapa sampah basah, kemudian dilakukan pencacahan sampah organik menjadi ukuran 1 sampai $2 \mathrm{~cm}$ yang tujuannya adalah memudahkan sampah tersebut terurai lebih cepat. Setelah itu cacahan sampah organik dimasukkan dalam tong sampah berukuran besar untuk didiamkan selama kurang lebih 4 minggu atau menggunakan larutan EM4 untuk mempercepat proses pembusukannya (Ekawandani \& Kusuma, 2018).

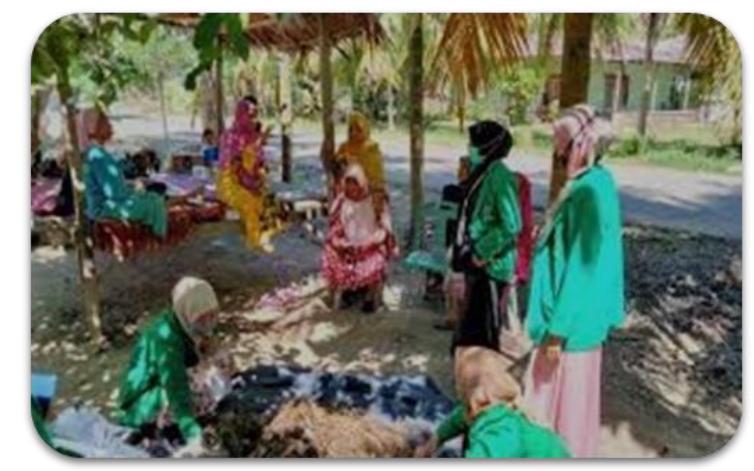

Gambar 4. Pendampingan pembuatan kompos 


\section{Memperbaiki sistem administrasi di TPST $3 R$ ke arah digital}

Tata kelola lembaga yang baik menjadi indikator syarat keberhasilan pengelolaan sampah berbasis masyarakat. Oleh karena itu pengelolaan sampah yang ada pada TPST 3R Langgeng Jaya harus mampu menyelenggarakan kegiatannya dengan sistematis mulai dari perencanaan kegiatan, pengorganisasian dan pengadaan tenaga kerja, pengarahan, pengkoordinasian, pelaporan dan penganggaran (Ichrom et al., 2015; Restuningdiah et al., 2021). Sebagian besar pencatatan yang dilakukan oleh TPST 3R Langgeng Jaya masih menggunakan sistem manual. Dari program pengabdian ini beberapa data pencatatan diubah menjadi digital, terutama pada pelaporan kas dan pembukuan per bulan, pelaporan sampah masuk dan penjualan sampah serta administrasi tenaga kerja dan job deskripsinya. Pembenahan yang dilakukan adalah memindah data manual dari buku untuk dimasukkan ke program Microsoft Excel. Pencatatan secara digital sangat membantu pengelola melakukan pembukuan secara cepat, rapi, akurat dan sistematis. Tim pengabdi juga mengedukasi bahwa kelebihan digitalisasi juga membantu pengelola mengarsipkan dokumen dengan bantuan IOT (Internet of Thing). Dengan merubah data dari manual ke digital diharapkan dapat memudahkan TPST 3R Langgeng Jaya dalam mengolah data dari pengguna jasa dan bagi SDM TPST 3R Langgang Jaya.

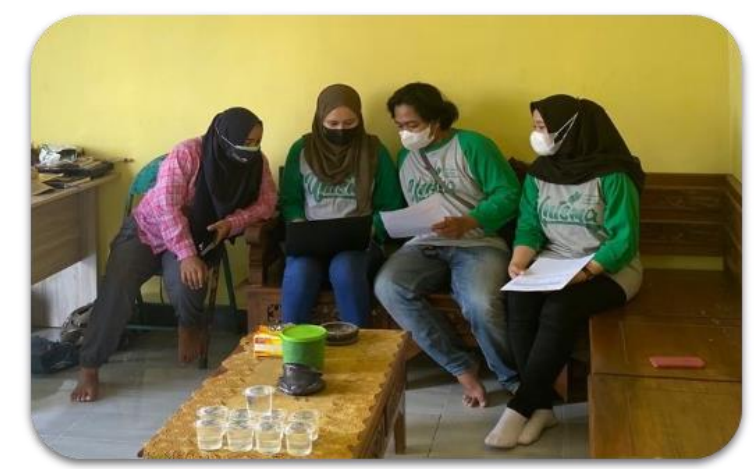

Gambar 5. Proses pemindahan data laporan pembukuan dan administrasi tenaga kerja ke Microsoft Excel

\section{Monitoring dan Evaluasi Program}

Monitoring dan evaluasi keberhasilan program pada pengabdian ini tidak diukur secara kuantitatif, melainkan dengan cara mengamati langsung perubahan yang terjadi pada perilaku masyarakat Dusun Cerme dan Segaran mengenai partisipasinya pada kegiatan PERILAKU HIDUP BERSIH yang dikampanyekan oleh tim pengabdi. Setelah diberlakukannya program, masyarakat mulai sadar untuk turut menjaga lingkungan dan berpartisipasi secara langsung dalam kegiatan memilih dan memilah sampah dari rumah. Kepedulian masyarakat terhadap pengurangan sampah juga mulai terlihat dari mulai menggunakan tas kain atau keranjang pada saat berbelanja di pasar. Beberapa warga juga mulai berpikir untuk memanfaatkan kompos yang dibuat dari sampah organik untuk diproduksi masal, yang rencananya akan dipergunakan untuk kebutuhan warga sendiri maupun kebutuhan pupuk para petani di situ. Evaluasi selanjutnya dengan melihat perbaikan administrasi TPST 3R Langgeng Jaya. Hasil yang didapatkan adalah pencatatan yang semula dicatat secara manual sudah ditransformasikan dengan pencatatan menggunakan program Microsoft Excel. 


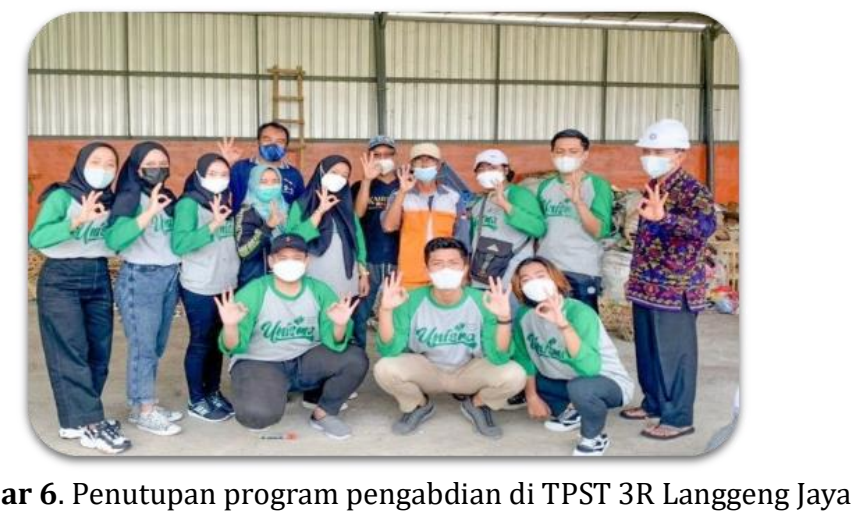

\section{KESIMPULAN}

Kegiatan pengabdian kepada masyarakat yang dilaksanakan mahasiswa KSM Unisma kel. 34 ini berangkat dari permasalahan yang ditemukan pada saat mengamati lingkungan sekitar. Kegiatan ini dilakukan dengan cara mengkampanyekan PERILAKU HIDUP BERSIH pada masyarakat dusun Cerme dan dusun Segaran, Desa Kendalpayak, Kabupaten Malang. Upaya yang dilakukan adalah dengan menggunakan pendekatan pemberdayaan masyarakat dengan mengajak masyarakat secara aktif dalam kegiatan manajemen sampah melalui kegiatan 3R (Reduce, Reuse dan Recycle). Hasil yang didapatkan adalah meningkatnya kesadaran dan partisipasi aktif masyarakat untuk melakukan pengurangan sampah serta memilih dan memilah sampah dari rumah. Selain itu menambah pengetahuan dan ketrampilan warga dalam mengelola sampah organik menjadi kompos. Serta telah dilakukannya perbaikan sistem pengelolaan di TPST 3R Langgeng Jaya secara digital, sehingga penyajian/laporan datanya lebih efektif dan efisien.

\section{DAFTAR RUJUKAN}

Ekawandani, N., \& Kusuma, A. A. (2018). Pengomposan sampah organik (kubis dan kulit pisang) dengan menggunakan em4. Jurnal TEDC, 12(1), 38-43. https://ejournal.poltektedc.ac.id/index.php/tedc/article/view/129

Elamin, M. Z., Ilmi, K. N., Tahrirah, T., Zarnuzi, Y. A., Suci, Y. C., Rahmawati, D. R., Kusumawardhani, R., P., D. M. D., Rohmawati, R. A., Bhagaskoro, P. A., \& Nasifa, I. F. (2018). Analisis Pengelolaan Sampah pada Masyarakat Desa Disanah Kecamatan Sreseh Kabupaten Sampang. Jurnal Kesehatan Lingkungan, 10(4), 368-375. https://doi.org/10.20473/jkl.v10i4.2018.368-375

Hartono, Y., Mardhia, D., Ayu, I. W., \& Masniadi, R. (2020). Pengelolaan dan Pemanfaatan Sampah Berbasis Rumah Tangga. Literasi Nusantara.

Hernawati, D., Saleh, C., \& Suwondo. (2005). Partisipasi Masyarakat Dalam Pengelolaan Sampah Berbasis 3R (Reduce, Reuse Dan Recycle) (Studi Pada Tempat Pengelolaan Sampah Terpadu Di Desa Mulyoagung Kecamatan Dau Kabupaten Malang). Jurnal Administrasi Publik, 1(2), 181-187. http://administrasipublik.studentjournal.ub.ac.id/index.php/jap/article/view/44

Ichrom, Y. N., Suryono, A., \& Hanafi, I. (2015). Manajemen Tempat Pengelolaan Sampah Terpadu Berbasis Masyarakat (Suatu Studi Pada Dinas Cipta Karya dan Tata Ruang dan Tempat Pengelolaan Sampah Terpadu di Desa Mulyoagung Kabupaten Malang). Jurnal $\begin{array}{llll}\text { Administrasi Publik } & \text { (JAP), } & 35-41 \text {. }\end{array}$ http://administrasipublik.studentjournal.ub.ac.id/index.php/jap/article/view/44

Marliani, N. (2014). Pemanfaatan Limbah Rumah Tangga (Sampah Anorganik) sebagai Bentuk Implementasi dari Pendidikan Lingkungan Hidup. Formatif: Jurnal Ilmiah Pendidikan MIPA, 4(2), 124-132. https://doi.org/10.30998/formatif.v4i2.146 
Rahim, M. (2020). Strategi pengolahan sampah berkelanjutan. Jurnal SIPILsains, 10(1), 3140. https://doi.org/10.33387/sipilsains.v10i1.1920

Restuningdiah, N., Nagari, P. M., Jati, F. D., \& Azzardina, A. (2021). Literasi bank sampah dan asuransi sampah sebagai upaya peningkatan kesejahteraan masyarakat. Jurnal Inovasi Hasil Pengabdian Masyarakat (JIPEMAS), 4(1), 144-152. https://doi.org/10.33474/jipemas.v4i1.9140

Roos, D. O. (2021). Sampah dan masalah sosial kemasyarakatan di ahuru air besar kota ambon. Hipotesa: Jurnal IImu-IImu Sosial, 15(1), 57-69. http://ejurnal.stiaalazka.ac.id/index.php/ojs-hipotesa/article/view/37

Sastropoetro, R. A. S. (1988). Partisipasi, komunikasi, persuasi dan disiplin dalam pembangunan nasional. Alumni.

Yunik'ati, Imam, R. M., Hariyadi, F., \& Choirotin, I. (2019). Sadar Pilah Sampah Dengan Konsep 4R (Reduce, Reuse, Recycle, Replace) Di Desa Gedongarum, Kanor, Bojonegoro. Jurnal Inovasi Hasil Pengabdian Masyarakat (JIPEMAS), 2(2), 81-87. https://doi.org/10.33474/jipemas.v2i2.1122 